\title{
思考過程の思考展開図表現に基づく機械設計支援システム Mechanical Design Support System Based on Thinking Process Development Diagram
}

\author{
間瀬 久雄 \\ (株) 日立製作所システム開発研究所 \\ Hisao Mase \\ Systems Development Laboratory, Hitachi, Ltd. \\ mase@sdl.hitachi.co.jp, http://www.sdl.hitachi.co.jp/ \\ 絹川 博之 \\ Hiroshi Kinukawa \\ 東京電機大学工学部情報通信工学科 \\ School of Engineering, Tokyo Denki University \\ kinukawa@im.dendai.ac.jp, http://www.cll.im.dendai.ac.jp/ \\ 森井 洋 \\ Hiroshi Morii \\ 東京大学大学院工学系研究科産業機械工学専攻 \\ Graduate School of Engineering, The University of Tokyo \\ morii@hnl.t.u-tokyo.ac.jp, http://hockey.t.u-tokyo.ac.jp/ \\ 中尾 政之 \\ Masayuki Nakao \\ 東京大学工学部附属総合試験所 \\ Engineering Research Institute, School of Engineering, The University of Tokyo \\ nakao@hnl.t.u-tokyo.ac.jp, http://hockey.t.u-tokyo.ac.jp/ \\ 畑村 洋太郎 \\ 工学院大学国際基礎工学科 \\ Yotaro Hatamura \\ Department of Basic Engineering in Global Environment, Kogakuin University \\ hatamura@hnl.t.u-tokyo.ac.jp , http://www.mech.kogakuin.ac.jp/global/globalhp/
}

Keywords: design system, knowledge management, design process, technology transfer, natural language processing.

\section{Summary}

This paper describes a system that directly supports a design process in a mechanical domain. This system is based on a thinking process development diagram that draws distinctions between requirement, tasks, solutions, and implementation, which enables designers to expand and deepen their thoughts of design. The system provides five main functions that designers require in each phase of the proposed design process: (1) thinking process description support which enables designers to describe their thoughts, (2) creativity support by term association with thesauri, (3) timely display of design knowledge including know-how obtained through earlier failures, general design theories, standard-parts data, and past designs, (4) design problem solving support using 46 kinds of thinking operations, and (5) proper technology transfer support which accumulates not only design conclusions but also the design process. Though this system is applied to mechanical engineering as the first target domain, it can be easily expanded to many other domains such as architecture and electricity.

\section{1. ま えがき}

企業活動の国際化が急速に進む中で企業を存続させ るためには, より強い製品競争力を持つことが不可欠で ある．強い製品競争力を持つためには, 設計作業の能率 向上だけでなく設計光のものの質の向上が必須である . 弚のためには, ( 1 ) 設計者の思考を刺激し, 競争力の強 い製品開発につながる独創的なアイデアを発想させるこ と，( 2 )同じ失敗を繰り返さないように他の設計者に技 術を正しく伝承し, 設計ノウハウの再利用を促進するこ と, という設計知識管理に関わる二つの設計課題の解決 が急務である。

上記設計課題を解決すべく，機械設計作業における設 計者の思考を直接支援する新しいシステムの開発につい
て検討してきた [Mase 01] . 本システムでは以下の3 点 を基本理念としている.すなわち，（a ) 設計者が機械設 計を行う際に辿る思考過程を，「要求/機能」(何をすべ きか, 何をしたいか),「機構」(要求/機能をどのように 実現するか)，「構造」(具体的にどう実現するか)の間の 脈絡付けを記述する「思考展開図」として表現すること，

（b）前記脈絡付けをする際に設計者が欲しくなる外部 支援を明確にし，光れらに対応する支援機能を基本機能 として提供すること，( c ) 設計の結論だけでなく光の思 考過程をも記録して技術を正しく伝承するための枠組み を提供すること，の3点である．

本論文では, 設計者の思考過程の表出化という観点か ら思考展開図の作成意義および特徵について述べる . ま た，思考展開図による思考過程の表出化を前提とした機 
械設計支援システムにおいて不可欠な 5 種類の支援機能 を提案し，各機能の役割およびシステム実装方法につい て詳述する．さらに，機械設計者による本システムの試 用評価によって得られた知見を踏まえて上記支援機能の 有効性について光れ午れ考察する .

機能分解や設計解の導出，思考内容の記述に関しては これまでに多くの研究がなされている . [Pahl and Beitz 88] では, 機能をエネルギー, 物質, 情報の「入 出力関係」と定義して機能分解を行う機能モデルについ て述べている．また[梅田 97] では，実体，実体間の 関連，物理現象からなり，状態の時間的遷移を表す「挙 動」を機能と関連付けて表現する F B S モデリングを提 案している.どちらも要求機能を下位機能に分解し，下 位機能を実現する設計解を導出し，設計解を具体化し， 元の機能を実現しているかを検証するという設計の流れ に沿ってモデリングをしており，この設計の流れは我々 の考え方と類似している．しかし，本論文で提案する思 考展開図表現に基づく方式では, 機能を言語 (動詞) と して表現される「作用」として捉えている．また，設計 者が発想した設計内容を思考展開図上に記述していく中 で, 要求/機能, 機構, 構造の脈絡付けが思考展開図記 述の理想形 ( 2 章参照) に近づくように, 思考展開図を 作成していくことで質の高い設計を実現することを目指 している。

また，[梅田 97] では，F B S モデリングに基づいて 機能分解や挙動との対応付け等を支援する機能設計ツー ル「F B S モデラ」を実装している．F B S モデラは， 定性推論システムによる挙動シミュレーションによって 非生起現象や副作用を設計者に提示する機能など , 設計 作業支援に有効な機能を備えた実用的なツールであるが， 以下の 4 点において我々の提案するシステムとは異なる .

（1）ＦＢＳモデラでは，機能分解 (アナリシス）の 領域と，挙動の対応付けおよびその統合 (シンセシス) の領域に分けて設計内容を記述しているが，多くの情報 が一つの図の中に記述されており, 図の一覧性を損なっ ていると考える.これに対して本論文で述べる思考展開 図では, 機能分解から構造展開/組立に至るまでの設計 内容および思考過程を, 要求, 機能, 機構, 構造という 構成により，左から右に一気通貫に記述しており，設計 内容の整理度を一覧できるようにしている。

( 2 ) 機械設計では, 要求機能からいきなり具体物 (思 考展開図では機構・構造に相当) を発想し，後に光の機 能を対応付けるという思考パターンがしばしば使われる が, F B S モデラはこの種の思考パターンに対応してい ないと思われる．これに対して我々のシステムでは，思 考展開図に基づいて設計を進める際に，機能，機構，構 造のどこからでも思考を始められるという柔軟性を有し ている .

（３）F B S モデラでは具体的に決まっていない対象 の機能分解支援が難しいが, 我々のシステムでは要求に
対して機能を分析 ·分解するためのヒントを与える枠組 みとして, 各種シソーラスや思考探索法則, 過去の設計 ノウハウを提示する機能を提供している .

(4) F B S モデラでは設計者の思考過程の記録につ いて支援していないが, 我々のシステムでは思考展開図 を作成するなかで, 思考順序や各種のメモ情報を設計内 容とともに記録する仕掛けを提供している .

独創的なアイデアを発想させて設計上の問題解決を 支援する手法として T R I Zがある [Fey 97]．ＴＲ I $Z$ は大量の特許文書を分析して, 人間が発明をする際に 辿る思考過程を客観的に抽出して法則化したものである． T R I Z では, 問題点を整理するために, 対立概念を選 択させたり，物質と場からなるサフィールドを記述させ たりする．これらにより設計者の抱える問題が T R I Z の法則を適用可能なレベルにまで抽象化できれば非常に 有効であるが, 実際の設計では光のレベルまで設計者自 身が問題を分析・整理・抽象化できないことが多い．こ れに対して我々の提案する方式では, 要求/機能 機構, 構造に沿って設計者の思考を整理して問題を分析・整 理·分解することにより, 問題の本質を明確にしている. また，TR I Zが解として提示する解決法は非常に抽象 的であり, 設計者の抱える問題のレベルにまで具体化し てあてはめることが難しい .これに対して本システムで は，実際の設計業務から経験的に得た 46 種類の客観的 問題解決手法（ＴＲＩＺの法則と区別すべく，以下「思 考探索法則」と呼引゙）を機械分野における具体的適用事 例とともに提示するので，提示された解決法を設計者の 抱える問題に適用しやすい.

T R I Z は冷戦終了後に欧米に流れ, 弚の後に日本に 紹介された手法であるが, 我々のシステムで扱う思考探 索法則は, 1980 年代後半から実際の設計現場におい て設計者の頭の中を観察する中で獲得してきたものであ り [畑村 88]，両者は法則の収集経緯および収集方法が 全く異なる．しかし, 両者を比較すると共通の法則が多 く見られることから，設計者の頭の中の動き方と光の利 用に対する考え方自体は非常に類似していると考える.

機械分野において質の高い設計を支援する研究とし て, 設計公理という理論が提案されている [Suh 90]. これは, 要求/機能と機構との間の相互干渉パターンか ら設計の矛盾や几長性を発見するものである . 本理論に よれば, 要求/機能と機構が互いに独立である場合, 光 の設計は良い設計であるとみなされる．本理論は設計の 矛盾や冗長な部分を発見する手法としては非常に有効な 手法であるが，発見された矛盾の解決を支援する方法は 提供していない．これに対して本システムでは，設計知 識の提示や思考探索法則の適用など , 矛盾や冗長を排除 する解決法の発見を支援する機能を提供している．

市場で要求される設計品質の設定を目的とした技法 としてQFD (Quality Function Deployment, 品質機 能展開) がある [水野・赤尾 78] . まず市場ニーズを収 


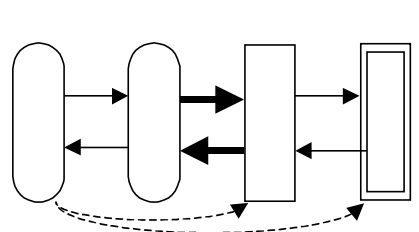

( a ) 機械設計者の思考の基本過程

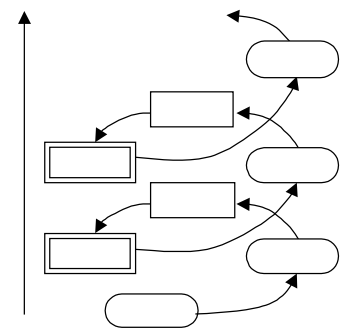

(b ) 思考のスパライル

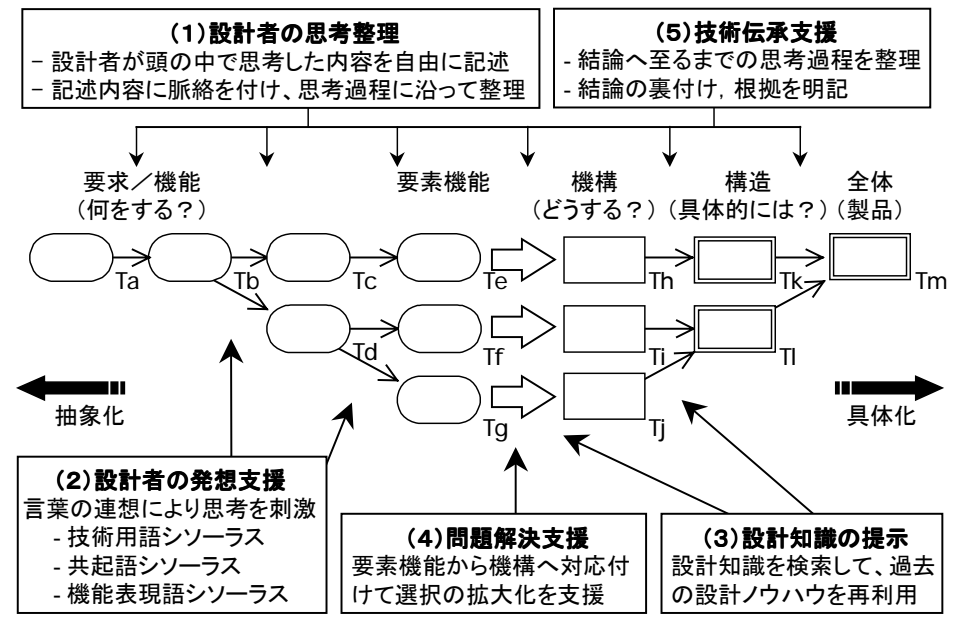

( c ）思考展開図の構成および各段階て設計者が欲しくなる五つの支援

图 1 機械設計時の設計者の思考過程と思考展開図（[畑村・中尾 00] の図を一部修正)

集して各々に重要度を設定し, 次に各ニーズの実現に必 要な技術特性を対応付け，さらに各技術特性を製品部品 に対応付ける．弚して市場ニーズから見た製品部品の重 要度を算出して比較し, 適切な設計指針を得る.思考展 開図とQF D とは互いに補完的な役割を示すと考えてい る.すなわち，QFDによって重要であると算出された ニーズを機能一機構-構造に展開し，設計を具体化する という連携方法が考えられる．

設計に限らず人間の思考内容を整理する従来手法と してKJ法が有名である [川喜田 67]．KＪ法は発想し た内容を次々に書き並べていき，類似する内容をグルー プ化してラベル付けし, グループ間に脈絡を付けていく ことにより思考を整理する手法であり，この手法を前提 とした発想支援ソフトウェアも数多く市販されている . 発想内容を書き並べて互いに脈絡を付けるという点で， 思考展開図の記述方法はK J 法と類似しているが , 思考 展開図では要求/機能 - 機構 - 構造という思考の基本過 程に沿って発想内容を明確に区別して記述させ，乥の間 の脈絡付けを促しており，これにより設計者の頭の中の 思考整理をより一層促進している点が大きな特徵である．

以下，2章ではまず本システムの前提となる設計者の 思考の基本過程および思考展開図について述べ，次に思 考の各フェーズにおいて設計者が必要とする外部支援を マッピングする．3章ではこれらの外部支援を実現する 設計支援システムの特長機能について述べる．4 章では 本システムの有効性について考察する .

\section{2. 機械設計における設計者の思考過 程と思考展開図}

機械設計における設計者の思考の流れを図 1 （ａ）の ように記述できる [畑村・中尾 00].ここでは，「機械 設計とは, 要求/機能 - 機構 - 構造の間の脈絡付けであ る」としている。「要求/機能」とは, 何をすべきか, 何
をしたいかという課題に相当する。機構」とは, 要求/ 機能をどのように実現するかという解決法に相当する .

「構造」とは，具体的にどう実現するかという具体策に 相当する.実際の設計では, 图1 (b) に示すように, 要求/機能 - 機構 - 構造の間を行きつ戻りつスパイラル に進むことにより，設計内容が深化・発展する[畑村 · 中尾 00$]$.

この思考の流れに基づいて思考過程を二次元平面上 に表現したものを「思考展開図」と呼ぶ . 思考展開図で は図 1 （c）に示すように, 要求/機能-機構-構造の 脈絡付けをノードとリンクを用いて言葉で記述する .

実際の設計では，市場分析やコンセプトの明確化，開 発コストの見積りなどを検討する「企画」段階がある． また，設計結果に基づいて実際に製作したり，製作され たものを実際に使用する「実行」段階がある．思考展開 图を作成する作業は「企画」と「実行」の間の (狭義の) 設計段階における作業として位置付けることができる .

機械設計において思考展開图を作成する場合，まず， 設計対象に課せられた要求/機能を分析し, 要素機能に 分解する . 次に , 個々の要素機能を実現する機構を 1 対 1 にマッピングする. 複数の機構で一つの要素機能を実 現するのは干渉設計と呼ばれる悪い設計である .この場 合, 要素機能をさらに細かく分解する必要がある 次に, 個々の機構を構造に具体展開し, 弚れらを組み合わせて 一つの製品を組み立てる. 実際の設計ではこれらのフ ェーズを試行錯誤的に繰り返す.図１（a）（c）の横軸 は時間軸ではなく抽象度であり，図の左から右へ進むに つれて設計内容が具体化する。

思考展開図の作成は機能, 機構, 構造の順で進むのが 理想であるが，実際の設計では設計者の思考は必ずしも この順序で進行しない . 課せられた要求からいきなり機 構や構造にジャンプ (図1 (a) 点線矢印) したり，機 構から光の機能に遡ったりすることがしばしばある．機 能 , 機構, 構造の順で思考展開図を作成することを設計 
者に強要すると, 思考弚のものが停滞してしまう，従っ て , 思考展開図を作成する際には, 思考順序のバリエー ションを許容し, 機能, 機構, 構造のどこから考えても 良いということを認めるべきである，ただし，思考展開 図の最終形態は, 图 1 （）に）に示すような理想形になっ ているべきである.すなわち, 機能が要素機能に分解さ れており, 各要素機能が機構と 1 対 1 に対応しており， 各機構か構造に展開されている思考展開図は質の高い設 計内容であるとみなすことができる．ある機構に対応す る機能が記述されていない場合に兴の機能を考えさせた り, 複数の機構が一つの要素機能を実現している場合に 产の要素機能をさらに分解させたりすることによって理 想形の思考展開図に近づけることにより，高品質の設計 に辿り着くことができる .

図1 (c) に示すように, 思考展開図は「抽象化一具 体化」の軸に沿って思考過程を記述・記録するものであ るが, 思考順序という時間軸に沿って思考過程を記録す ることも可能である. 図 1 ( c c ) の思考展開図を構成す る各ノードに光の生成順序を表す番号 (図 1 （c）では 変数 $\mathrm{Ta}, \mathrm{Tb} ， . .$. を用いて記述している) を付与すること により，設計者がどういう順序で思考を進めたのかを容 易に理解できる。

このように，「抽象化一具体化」の軸と時間軸に沿っ て設計の思考過程を思考展開図として表現することによ り, 機能 - 機構 - 構造の間の脈絡付けが適切に行われて いるかを容易にチェックできるとともに，他の設計者に 設計内容および思考過程を正しく伝達することができる．

次に，思考展開図に基づいて機械設計を進めるときに， 图 1 ( c ）にも示すように, 以下の 5 種類の設計者支援 が必要であると考える.

(1) 設計者の思考整理

設計全体にわたって設計者が頭の中で思考した内容 を記述整理する作業を支援する，弚のためには，思い浮 かんだ事柄を言葉や絵で自由に記述し, 記述内容に脈絡 を付けて整理する作業場が必要となる。

( 2 ) 設計者の発想支援

発想した概念から別の概念を連想させることにより 設計者の思考を刺激し，柔軟な発想を支援する．乥のた めには, 言葉 (概念) の関連を記述したシソーラスが必 要となる.本論文では,「シソーラス」という言葉を広い 意味で使用している．すなわち, 言葉間の関連として上 位/下位関連だけでなく,同意/類義関連や共起関連 ( 3 章参照) などを含むものとしてシソーラスを定義する .

( 3 ) 設計知識の提示

過去の失敗事例から得られる教訓, 設計の定石, 部品 の規格や、関連特許, 過去の設計事例等を知識データベー ス化し, 設計者が「必要なときに必要な形で」参照する ことを支援する．弚のためには，設計者が検索・参照・ 理解しやすいように, データを知識化しておく必要があ る.また，機械分野では要求/機能を記述する際に使わ
れる動詞をキーワードとした検索が必須である .さらに， 設計者や設計部署, 設計分野の違いにより, 同じ概念を 異なる言葉で表現することが多いので, 言葉の表記を統 一するシソーラスが検索精度向上には不可欠となる．

(4) 問題解決支援

ある要求/機能を実現する機構, 構造に対して, 光の 機構，構造に付随する「制約条件」(「負の機能」とも呼 ばれている) がしばしば発生する．制約条件を解消でき ない場合，全く別の機構，構造を検討しなければならな い. 光のため, 制約条件を回避しつつ要求/機能を満た す機構，構造の発見を支援する仕掛けが必要となる．

( 5 ) 技術伝承支援

設計内容を保存して再利用することは設計の効率化 につながる．しかし，設計の結論 (採用した設計内容) だけを残しておくだけでは設計の再利用はなされない . なぜ产の結論に至ったのかに関する思考過程や，途中で 棄却された設計案か記録されていないからである . 光こ で, どのような思考過程に基づいて光の設計が行われた のか，どのような根拠／裏付けによって設計内容を決定 したのかを設計結果に明記して伝承する仕掛けが必要と なる

\section{3. 機械設計支援システムの特長機能}

我々は図 1 の思考展開図に基づき，2 章で述べた 5 種 類の外部支援を基本機能として搭載した設計支援システ ムを開発している．本システムは機械分野を対象として いるが，建築，情報処理など他分野における設計や，番 組やイベントの企画, 日常生活におけるありふれたたテー マに対しても大筋において適用可能である.ただし，後 述する各種データベースについては分野に応じて最適な コンテンツを用意して置き換える必要がある．

以下 , 本システムの 5 種類の基本機能の詳細を述べる .

(1) 設計者の思考整理機能

本システムでは, 設計者の思考内容を図 2 に示す画面 上に思考展開図として整理するエディタを提供する．思 考展開图を記述する形式として, 視覚的理解が比較的容 易な, ノードとリンクからなるグラフ構造を採用する． ノードは概念を表し，リンクで結ばれたノード同士は互 いに脈絡 (意味的関連) があるとする。また，ノードの 形によってノードの種別を区別する . 要求/機能は角丸 四角形，機構は長方形，構造は二重四角形，制約条件は 二重角丸四角形, 思考探索法則は六角形, 光の他はノー ド枠なしで表す．ノードノリンクは自由に生成・移動・ 複写・削除・修正することができる。

图 2 は思考展開図の作図例を示す .ここで，ノード右 下の番号はノードの生成順序を表している .この番号順 に思考展開図を辿ることにより，設計者の思考順序をよ り正確に理解できる . 太線のノード/リンクは光の設計 内容を最終的に採用したことを示している．ノード/リ 


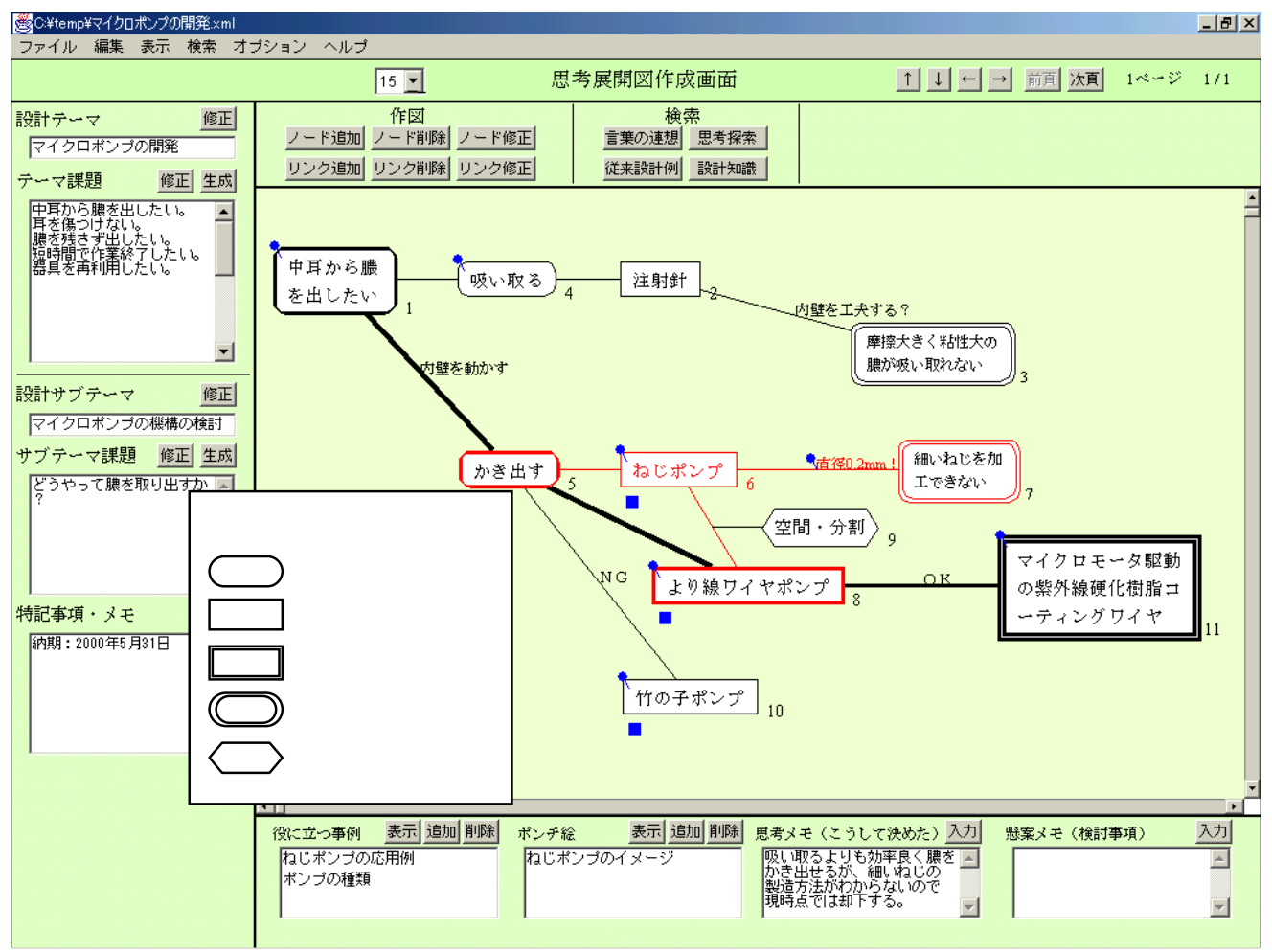

图 2 本システムのメイン画面構成および思考展開図作成例（ノード 6 を選択した状態）

ンクにはメモ情報（役に立った情報のアドレス，ポンチ 絵 (イメージデータ)，文章メモ) を貼り付けられ，ノー ド左下の四角 (口) はポンチ絵の貼付を , ノード/リン クに刺さったピンマークは文章メモや役に立った情報の アドレスの貼付を示す .

( 2 ) 設計者の発想支援機能

設計者の発想を発散/収束すべく, シソーラスを検索 する機能を提供する (図 3 ) .最初にトリガとなる言葉を 画面左上のフリーワード闌に入力すると, 光の言葉から 連想される言葉が画面下部に表示される.表示された言 葉を次々に選択することにより，シソーラスを連続して 検索できる

本システムでは，機械分野に関する以下の 4 種類のシ ソーラスデータを収録している (表1)。

( a ) 技術用語シソーラス

ある言葉に対して多くの設計者が共通して連想する 言葉を集めたシソーラスである．40人の機械設計の専 門家によって手作業で作成された 10,276語,25,548 リン

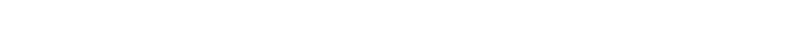
能, 機構, 構造, 弚の他のどれか一つに分類されている ので, 機能から機能, 機能から機構・構造, 機構・構造 から機能というような言葉の連想が可能である.

(b) 特許共起語/記事共起語シソーラス

専門家の手作業による技術用語シソーラスの語数お よびリンク数を補い, 幅広い連想を可能とすべく, 計算 機によって関連の強い言葉対を自動抽出して補完してい る.ここでは, 機械設計に関連するテキスト文書から，
ある言葉と対になって出現する傾向の強い言葉（以下， 共起語と呼ぶ）を自動抽出し [間瀬 97] , 人手チェック を経てシソーラスとして追加格納している.テキスト文 書として, 特許公開公報 21,594 件と, 新聞記事データ 17,337 件を用意し，特許公開公報からは 33,403 語,552,617 リンク，新聞記事データからは 17,155 語， 386,679 リンクの共起語データを抽出し，検索可能とし ている .

（c）機能表現語シソーラス；機能の連想

機械分野において要求/機能を記述する際に使われ る動詞を収集し，階層木構造として体系的に緾め上げた シソーラスである．表現は異なるが共通の意味を持つ言 葉群が一つの下位グループを形成し, 各下位グループに は产のグループを代表する標準語が定義されている．光 して，概念的に類似するいくつかの下位グループがまと まって中位グループを形成し，中位グループがさらにま とまって上位グループを形成している．本データは 40 人の機械設計の専門家によって手作業で作成された 2,084 語（6 上位グループ，72 中位グループ，598 下位 グループ) の動詞データで構成される .

機械設計では，ある機構・構造の代替案を検討すると き，光の機構・構造の機能は光も光も何か (何をしたい のか）について再考し，兴の機能から上位機能に上がっ てみる (抽象化する) ことが代替案を発想する有効な手 段の一つである．弚こで本シソーラスを用いることによ り，機能のレベルで発想を抽象化／具体化することを支

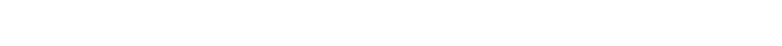




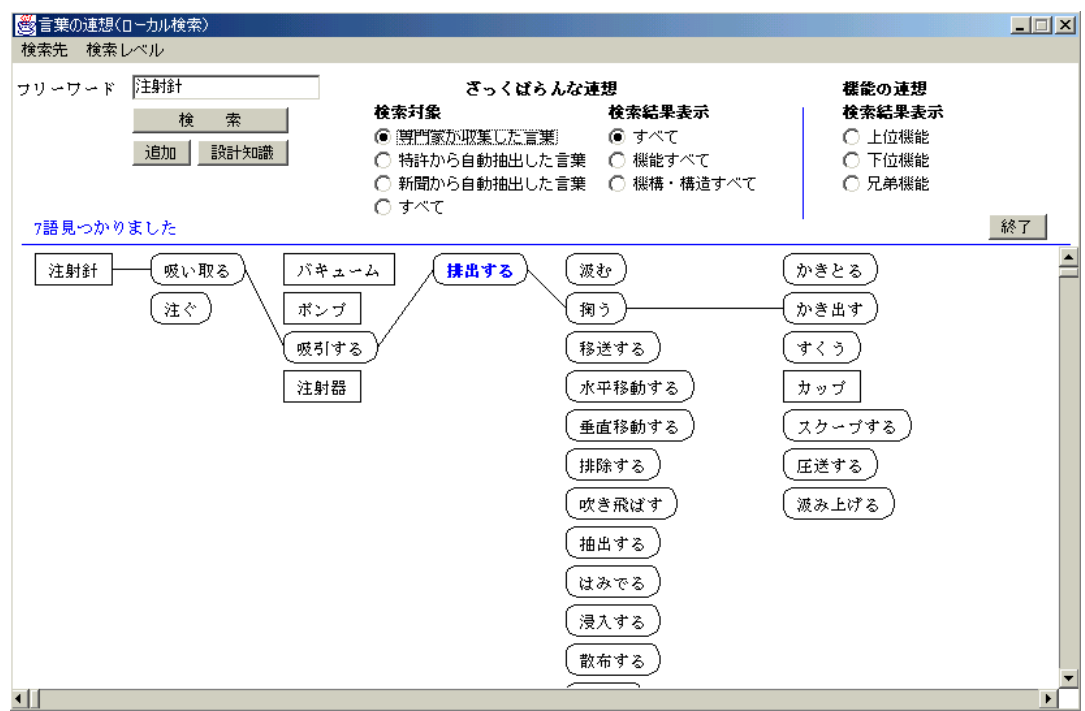

图 3 シソーラス検索による発想支援

連想された「吸引する」という動詞について，機能表現 語シソーラスを検索することにより中位づループ「排出 する」を検索し，弚の下位グループをさらに検索するこ とにより，「吸引する」と概念的に類似する動詞(「汲む」, 「掬（すく）う」等）を連想している．

このように，図3の画面では技術用語シソーラスや共 起語シソーラスを検索対象とした「ざっくばらんな言葉 の連想」と，機能表現語シソーラスを検索対象とした「機 能の連想」を選択的に使い分けることにより，設計者の 意図に合致した言葉の連想を支援している.

(3) 設計知識の提示機能

設計者が必要とする設計知識をタイムリーに提示す る機能を提供する . 図 4 左下は設計知諳検索を行う画面 である．本システムでは, 電機, 自動車, 鉄鋼, 精密機 器などに属する日本企業 10 社から収集した定石, 失敗 事例を含む 800 件の設計知識データを収録している。 本システムに収録されている設計知識データはすべ て知識化が施されている.第一に, 各設計知識の中でノ ウハウとして伝えたいことを「設計のアドバイス」とし て簡潔に記述している.第二に, 弚の設計知識を必要と するのはどんな設計者か, どんなときに光の設計知識が 欲しくなるかを考慮して, 各設計知識に複数の知識キー ワードを付与している.これらは「〜で〜を〜する」「〜
が〜する」といった簡潔な文で記述定義している．

図 4 右上に設計知識の一例を示す.設計知識データは 以下の構成要素からなり，XML (Extensible Markup Language) で記述されている .

（a）知識名称：設計知識の内容を端的に記述. 主夕 イトルと副タイトルからなる。

(b) 知識種別: 知識内容の種別 (定石・失敗・規格 · 特許）と，思考展開図における段階（機能・ 機構・構造) と知識内容との対応情報を記述 (企画段階や実行段階の知識も収録).

（c）入力日：設計知識データの作成日を記述 .

(d) 知識キーワード：知識内容を短文で簡潔記述 .

(e) 知識レベル : 内容の難しさを 5 段階で記述 .

（f）思考探索種別：思考探索法則の分類を記述 .

(g) 関連設計知識ファイル名称 :

関連設計知識のアドレスを記述 .

( h ) 説明文 : 設計知識の内容を文章で記述 .

（i ）図表種別: 挿入する図面が図か表かを記述.

（j）図表タイトル：図表のタイトルを記述 .

（k）図表ファイル名称：図表のファイル名を記述.

（）図表説明：图表に対する補足説明を記述。

( m ) 設計のアドバイス : 得られる教訓, 設計者が注 意すべきことを記述 .

表 1 本システムが提供するシソーラスデーター覧

\begin{tabular}{|c|c|c|c|c|c|}
\hline$\#$ & 名称 & 提供の目的 & データ内容 & デー夕規模 & 作成者 \\
\hline 1 & $\begin{array}{l}\text { 技術用語 } \\
\text { シソーラス }\end{array}$ & 機械技術用語の連想支援 & $\begin{array}{c}\text { ある技術用語から連想される技術用語群 } \\
\text { (各用語は, 機能/機構／構造の属性を持つ) }\end{array}$ & $\begin{array}{c}10,276 \text { 語 } \\
25,548 \text { リンク }\end{array}$ & $\begin{array}{l}\text { 機械設計者 } \\
40 \text { 名 }\end{array}$ \\
\hline 2 & $\begin{array}{l}\text { 特許共起語 } \\
\text { シソーラス }\end{array}$ & $\begin{array}{l}\text { 機械技術用語の連想支援 } \\
\text { (技術用語シソーラスを補完) }\end{array}$ & $\begin{array}{c}\text { ある言葉と対になって出現しやすい } \\
\text { (共起する) 言葉群 }\end{array}$ & $\begin{array}{c}33,403 \text { 語 } \\
552,617 \text { リンク }\end{array}$ & $\begin{array}{c}\text { 計算機 } \\
+ \text { 人間チェック }\end{array}$ \\
\hline 3 & $\begin{array}{l}\text { 記事共起語 } \\
\text { シソーラス }\end{array}$ & $\begin{array}{l}\text { 機械技術用語の連想支援 } \\
\text { (技術用語シソーラスを補完) }\end{array}$ & $\begin{array}{c}\text { ある言葉と対になって出現しやすい } \\
\text { (共起する) 言葉群 }\end{array}$ & $\begin{array}{c}17,155 \text { 語 } \\
386,679 \text { リンク }\end{array}$ & $\begin{array}{c}\text { 計算機 } \\
+ \text { 人間チェック }\end{array}$ \\
\hline 4 & $\begin{array}{l}\text { 機能表現語 } \\
\text { シソーラス }\end{array}$ & $\begin{array}{l}\text { 機能を表寸動詞の連想支援 } \\
\text { 設計知識検索において動詞 } \\
\text { キーワードを標潐語に変換 }\end{array}$ & $\begin{array}{l}\text { •機能を表す動詞の上位/下位機能を表寸動詞群 } \\
\text { •機能を表す動詞と共通の概念を持つ動詞群及び } \\
\text { その動詞群を代表する標準語 }\end{array}$ & 2,084 語 & $\begin{array}{c}\text { 機械設計者 } \\
40 \text { 名 }\end{array}$ \\
\hline
\end{tabular}




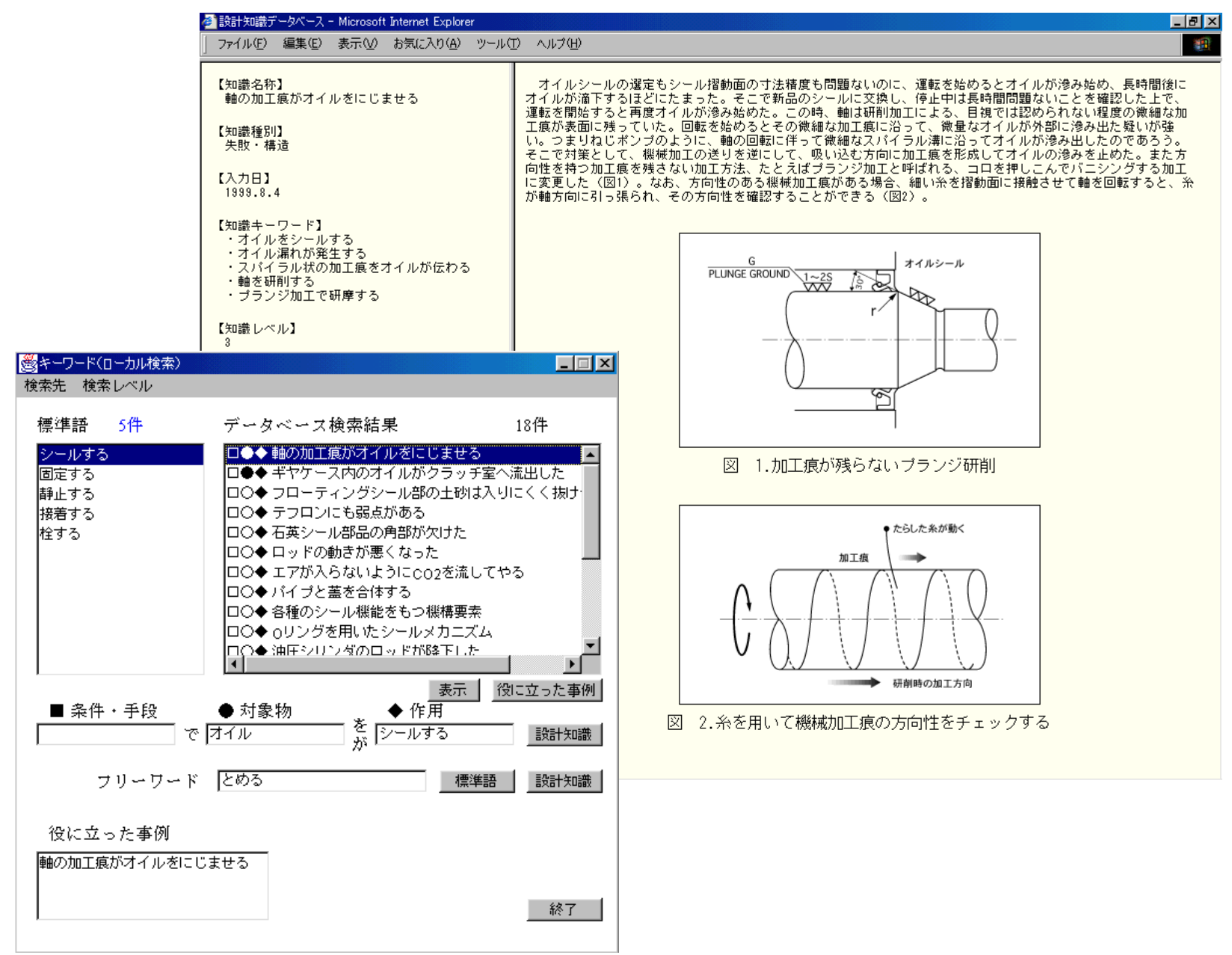

图 4 設計知識の検索インタフェースと設計知識の例

( n ) 思考探索説明 : 思考探索法則の適用に関する説 明を記述。

（ｏ）非技術的背景：技術以外の観点で記述.

機械設計では，機構の観点からの検索でなく，機能の 観点からも検索したいというニーズが高い，一般に，機 構は名詞を用いて記述され，機能は動詞を用いて記述さ れる.乥こで, 本システムの設計知識検索では, 名詞 (機 構)，動詞 (機能) の両方をキーワードとして受容してい る . 動詞をキーワードとして検索する場合 , まず機能表 現語シソーラスからその動詞キーワードの属するグルー プの標準語を検索して設計者に提示する . 設計者は自分 の入力した動詞キーワードを, 意味的に最も近い標準語 に置き換えることにより，漏れの少ない検索結果が得ら れる . また，機能表現語シソーラス中の動詞毎に検索条 件入力用のテンプレートを用意している . 動詞に対する 主語や目的語 (対象物)，手段等を表す言葉を検索キー ワードとしてテンプレートに追加入力することにより， 所望の設計知識を低ノイズで検索できる．

図 4 では, 最初に動詞キーワード「とめる」が入力さ れており,対応する標準語として「シールする」「固定す る」など 5 語が提示されている. 弚の中から「シールす
る」を選択すると，「シールする」に対応するテンプレー 卜「(条件・手段) で (対象物) をシールする」が画面中 央に表示される．ここではシールする対象物として「オ イル」を検索キーワードとして追記し，「オイル」「シー ルする」の二つをキーワードとして検索している．検索 結果 18 件のうち, 上位 2 件は両方のキーワードがヒッ 卜した設計知識であり, 設計者の所望する設計知識に内 容的により近いものとして上位に提示している .

(4) 問題解決支援機能

1 章で述べたように，本システムでは，ある要求/機 能を実現する解決法と艺こから派生する制約の間に起こ る対立/矛盾を解決する客観的手法である思考探索法則 を兴の具体的適用事例とともに提供する . 思考探索法則 は，表 2 に光の一部を示すように，大分類 6 種類と小分 類 46 種類から構成される.

しかし, 法則数が多いため, どの法則が設計者の直面 している問題の解決に有効であるかを絞り込む機能がな いと, 設計者は 46 種類すべての法則をチェックしなけ ればならなくなり，非常に効率が悪い．

そこで, 本システムでは, 各思考探索法則と問題を記 述する際に使われる作用 (動詞) との間の対応関係に着 


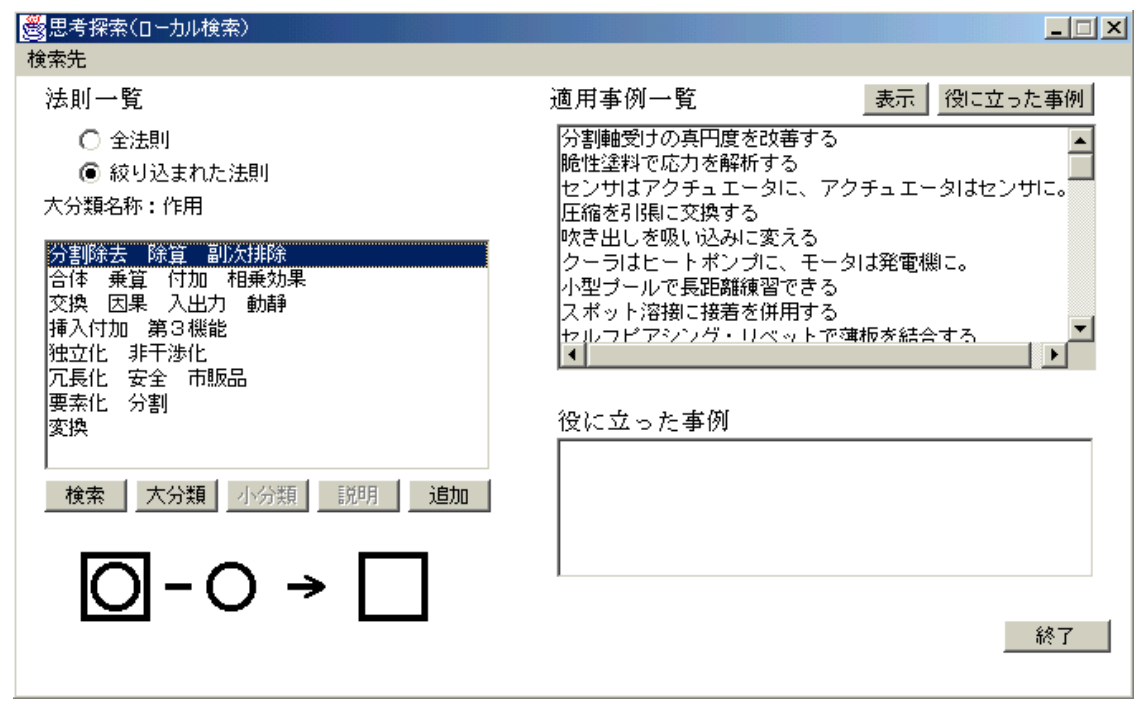

图 5 問題解決支援画面 (思考探索法則の適用)

表 2 思考探索法則 (一部抜粋)

\begin{tabular}{|c|c|c|}
\hline 大分類 & 小分類 & $\begin{array}{c}\text { 関連の深い } \\
\text { 動詞上位 } \\
\text { グループ }\end{array}$ \\
\hline \multirow[t]{3}{*}{ 空間 } & 【分割，分散，除去, 減算】 & \multirow[t]{3}{*}{ 動かす } \\
\hline & 【合体, 集合, 一体化, 加算】 & \\
\hline & など 8 種類 & \\
\hline \multirow[t]{3}{*}{ 物質 } & 【相変化・蒸発・消失】 & \multirow[t]{3}{*}{ 強くする } \\
\hline & 【集合・セルフアセンブリ・凝集】 & \\
\hline & など 7 種類 & \\
\hline \multirow[t]{3}{*}{ 時間 } & 【直列・順次・シーケンス・分割】 & \multirow[t]{3}{*}{ 測る } \\
\hline & 【バイパス・分流・分割・並列】 & \\
\hline & など 8 種類 & \\
\hline \multirow[t]{3}{*}{ 作用 } & 【分割除去·除算・副次排除】 & \multirow[t]{3}{*}{ 作る } \\
\hline & 【合体・乗算 $\cdot$ 付加 $\cdot$ 相乗効果】 & \\
\hline & など 8 種類 & \\
\hline \multirow[t]{3}{*}{ 現象 } & 【再生・バイオ・生体】 & \multirow{3}{*}{$\begin{array}{c}\text { 状態変化 } \\
\text { する }\end{array}$} \\
\hline & 【光波・レーザ・液晶】 & \\
\hline & など 7 種類 & \\
\hline \multirow[t]{3}{*}{ 制約 } & 【組織・会社・人事・家庭】 & \multirow[t]{3}{*}{ 考える } \\
\hline & 【環境・地球・公害・リサイクル】 & \\
\hline & など 8 種類 & \\
\hline
\end{tabular}

目する .すなわち , 表 2 に示すように，思考探索法則の 大分類 6 種類は , 機能シソーラスの上位グループ 6 種類 とほぼ1対 1 に対応する傾向にあるという事実を利用し て, 適用可能な思考探索法則を絞り込む．例えば，図 2 の思考展開図では,「ねじポンプ」という機構を記述した ノード 6 と，「細いねじを加工できない」という制約条件 を記述したノード 7 との間で設計上の対立が起こってい るが ,両ノード中に出現する動詞に着目すると，「加工で きない」という動詞が使われている．機能表現語シソー ラスを検索することにより，この動詞が「作る」という 上位グループに属することが分かるので, 表 2 より上記 対立関係を解決するためには「作用」に属する思考探索 法則が有効であると判定し，「作用」に属する８種類の思
考探索法則だけを設計者に提示する．設計者は各法則の 定義と产の法則を適用した事例を参照することにより， 光の法則を自分の問題にあてはめ, 解決策を模索する.

図 5 に問題解決支援画面を示す．画面左側のリストの 一行が一つの法則を示している 法則を一つ選択すると， 兴の法則の意味を端的に表すポンチ絵が画面左下に表示 される.また，「検索」ボタンを押すと光の法則に対応す る適用事例一覧が画面右側に表示される . 適用事例の記 述フォーマットは, 本章 (3) で述べた設計知識データ と同一である .

( 5 ) 技術伝承支援機能

技術伝承に関する情報の入力はなるべく設計者の手 間をかけないようにすることが肝要である . 本システム では図 2 に示すように，ノード生成時に各ノードの右下 に炎のノードの生成順序を示す番号を自動付与する .こ の番号を辿ることにより, 設計者がどのような順序で思 考を展開したのかをより正確に理解できる．また，任意 のノードやリンクに対してメモやポンチ絵 , 意思決定に 影響を及ぼした設計知識アドレス $(U R L)$ などの貼付 をアイコンで示しているので，他の設計者が作成した思 考展開図でも，設計内容および思考過程を漏れなく効率 良くチェックできる．

\section{4. 本システムの有効性に関する評 価・考察}

本システム開発の初期段階から，東京大学，金沢大学， 東海大学の機械系学生と, 企業設計者 40 名による実適 用評価を行ってきた . 以下, 本システムの五つの基本機 能の有効性を，被験者の意見を織り交ぜながら考察する．

（1）設計者の思考整理機能

本システムを用いて思考を中断させずに思考内容を 記述できるかを考察する．被験者からは，「編集しやす 
い」,「きれいな形で残せる」,「ノード移動やリンク付け 替えが容易で, 発想の組立が簡単にできる」などの肯定 的意見を得た，一方，「ある程度思考がまとまった時点で 乥れを整理する道具として有効」「構造のレベルでは言 葉より絵の方か理解しやすい」という意見も得た . 本シ ステムでは, ポンチ絵データの作成は別のアプリケーシ ヨンに委ねており，作成された電子データを思考展開图 にリンク付けする機能のみを提供しているが，より気軽 に絵を描ける環境の提供は今後の課題である.

思考整理機能に関する被験者の反応は概ね良好であ つたが, 被験者は機械設計者の思考過程や思考展開図に ついて理解している，または事前に説明を受けている設 計者である . 事前知識の全くない設計者が本システムを 使いこなすためには，思考展開図の意義および作成方法 などに関する事前導入教育の実施が必要であり，乥の教 育カリキュラムの早期確立が急務である .

( 2 ) 設計者の発想支援機能

シソーラスについては, 光の内容か設計者の設計分野 と合致している必要があるため, 評価か難しい .ここで は言葉の連想による発想支援の有効性について考察する 被験者からは，「シソーラスの探索により思考か楽しく できる」、「言葉を考える負担が少なく思考のスピードが 速くなる」という肯定的意見を得た .一方，「言葉の連想 が発散してしまい収束しない」,「網羅する分野が狭い」,

「有用なヒントとなる言葉がなかなか出ない」という否 定的意見も得た . 本システムでは選択した一つの言葉の みから連想される言葉を検索しているため, どちらかと いうと連想を発散させる傾向か漒い . 共起語については 弚の傾向が特に強い, 連想を収束させるためには, 過去 の言葉の連想の流れを考慮して複数の言葉から連想され る言葉を絞り込むなど，アルゴリズム上の工夫が必要で ある.また, シソーラスデータ高のものについても，連 想の発散，収束を考慮して体系化する必要があろう。

(3) 設計知識の提示機能

被験者からは，「共通する考え方を理解するのに有 効」,「背景知識を習得するのに便利」という意見を得た . 一方，「見積資料や業務手順などのデータベースとの連 携が必要」,「W e b ページやフリー特許検索サイトとリ ンクした強力な検索機能が欲しい」という要望もあった . また，本システムでは知識キーワードのみを検索対象と しているため低ノイズの検索結果が得られるが，光の反 面，「有効な知識がなかなかヒットしない」という意見が あった .これは知識キーワードの質の問題よりも，設計 分野の相違と 設計知識が十分に網羅されていないこと， 名詞のシソーラスの未装備による検索アンマッチの三つ が大きな原因であると考えている.設計知識に記述され ている知識キーワードは誰にでも付与できるものではな く, 設計経験の豊富なマネージャクラスの人が作成する ことを前提としている．どのような観点から知識キー ワードを付与すると検索に有効であるかについて整理し，
設計知識作成時にガイダンスする機能が必要であろう．

(4) 問題解決支援機能

本機能は，機構・構造と光こから派生する制約条件の 間に起こる設計上の対立や矛盾のうち，発想を転換しな いと解決策を発見することが困難な問題の解決を支援す る機能であるため，本格的な設計業務の中で実際に問題 に直面したときでないと使われない機能である．これま での評価では，解決が困難な問題を扱うような設計テー マで行っていないため，本機能に関する有益な意見は得 られていない . 今後, 実際の設計業務に本システムを適 用し，光の中で発生した問題を本機能て解決できるかを 評価していく予定であるが，個々の思考探索法則の意義 やイメージを体系的に説明し，各法則に対する設計者の 理解をより促進するガイダンス機能の拡充が必須である と考えている。

(5) 技術伝承支援機能

思考展開図のノードに番号付けをしたり，種々のメモ を付けられるという機能は，「技術伝承に有効である」と いう意見が大半であった 一方で,「複数の人の間で思考 を共有したい」、「整理した内容を他人に説明するのに便 利」など, 思考結果を複数の設計者で共有していくため の仕掛け作りが必要であるという意見を得た . 本システ ムで作成された一つの思考展開图をべースに，先生と学 生，あるいは設計者グループの間で設計レ゙ューができ るような機能拡張が有効であると考える．また， C A D データと思考展開图データとを結び付け，CＡＤ图面か ら関連する思考展開図を呼び出すことにより, 設計レビ ユーや技術伝承をより促進できると考える．

本システムは上記五つの機能によって設計者の思考 を支援するが これらの機能を複合させることによって， より高度な設計支援を実現できる，例えば，シソーラス による連想によって獲得した言葉で設計知識データベー スを検索したり，設計知識に記述されている言葉から新 たな連想を始めたり，思考探索法則を用いて問題解決を 行う際に, 機能表現語シソーラスを検索して問題点を整 理・分析したりするなど, 複数の機能を必要に応じて組 み合わせることにより，設計者の発想をより高め，質の より高い設計結果を得ることができると考える .

\section{5. むすび}

本論文では, 設計の思考過程の記述による思考整理お よび設計の正しい伝承を支援する機械設計支援システム について述べた．まず，機械設計において設計者が要求 /機能 - 機構 - 構造という思考過程に沿って思考を整理 する枠組みである思考展開図について述べた . 次に , 思 考展開図作成を前提とした機械設計において設計者か欲 しくなる支援として，（1）設計者の思考整理，（2）設 計者の発想支援， (3) 設計知識の提示, (4) 問題解決 支援，（５）技術伝承支援，の五つを提案した。また，こ 
れらの支援機能を搭載した具体的な機械設計支援システ ムを開発した .さらに, 異企業の機械設計者 40 名によ る実適用評価と機械系学生の実習での使用により，機械 設計時において, 上記 (4) を除く本システムの四つの 支援機能について钅の有効性を確認した．現在も，機械 分野の大学・企業において, 上記支援機能 (4) の有効 性の検証を含めた本システムの評価を広く推進している． また，本システムを機械設計以外の分野において適用す ベく, システムの汎用化についても今後検討していく予 定である .

本システムは, 設計者個人の思考整理に有効であるほ か, 大学や企業における教育支援ツールとしても有効で あると考えている.生徒がある設計テーマについてどの ような発想で取り組んでいるか, どこまで理解できてい てどこで悩んでいるのかを, 講師は思考展開図から読み 取り, 適切なアドバイスを生徒に与えるといった教育ス タイルが可能となる．ただし，本システムを使えば誰で も必ず設計の質が向上するわけではない．設計の本質を 体得させるために, 本システムを核とした導入教育方法 を確立することも今後の大きな課題である .

なお，本プロジェクトは日本自転車振興会の支援を頂 き, 平成 10 年 10 月から平成 13 年 6 月まで行われた . また, 本システムの開発を支援頂いた経済産業省, (財) 機械システム振興協会, (社)電子情報技術産業協会の関 係者, 光して本システムに収録されている各種データの 収集および編集に携わった諸氏に深く感謝する。

\section{$\diamond$ 参 考 文 献 $\diamond$}

[Fey 97] Fey, R. V. and Rivin, I. E. : T R I Z 入門, 日刊工業 新聞社 (1999)

[畑村 88] 畑村洋太郎：実際の設計 - 機械設計の考え方と方 法一，日刊工業新聞社 (1988)。

[畑村 92] 畑村洋太郎編著: 続・実際の設計 一機械設計に必 要な知識とデーター，日刊工業新聞社 (1992)．

[畑村 96] 畑村洋太郎編著: 続々・実際の設計 - 失敗に学ぶ - , 日刊工業新聞社 (1996) .

[畑村・ 中尾 00] 畑村洋太郎, 中尾政之: 設計者が欲しい設計 支援システムの開発，情報処理学会誌 Vol.41, No.7, pp.862-867 (1999)

[川喜田 67] 川喜田二郎 : 発想法, 中公新書 136, 中央公論社 (1967) .

[Mase 01] Mase, H., Kinukawa, H., Morii, H., Nakao, M. and Hatamura Y. : Creative Design Support System Based on Disigner-Thinking-Process Model, Proceedings on 8th IFAC/IFIP/IFORS/IEA Symposium on Analysis, Design, and Evaluation of Human-Machine Systems (2001) .

[間瀬 97] 間瀬久雄, 德田圭世, 森本由起子, 辻洋, 丹羽芳樹 : WWWホームページからの共起語自動抽出実験, 情報処理 学会第 55 回全国大会講演論文集 3-72,73 (1997)

[水野. 赤尾 78] 水野滋, 赤尾洋二: 品質機能展開, 日科技連 出版社 (1978)

[中尾 99] 中尾政之 : 設計のナレッジマネジメント, 日刊工業 新聞社 (1999).

[Pahl and Beitz 98] Pahl, G. and Beitz, W. : Engineering Design: Systematic Approach, Springer-Verlag, Berlin
(1988) .

[Suh 90] Suh, N. P. : The Principles of Design. Oxford University Press (1990).

[梅田 97] 梅田靖, 冨山哲男, 吉川弘之 : 機械設計支援のため のF B S モデリングの提案, 精密工学会誌, Vol.63, No.6, pp.795-800 (1997).

〔担当委員 : 冨山哲男〕

2001 年 8 月 3 日 受理

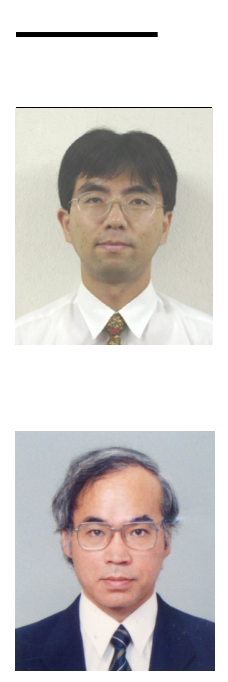

\section{者 紹 介}

\section{間瀬 久雄}

1965 年生. 1990 年名古屋大学大学院工学 研究科情報工学専攻修了. 同年 (株) 日立 製作所システム開発研究所入社, 現在に至 る.1997 年スタンフォード大学客員研究員. 専門は自然言語処理, 文書分類, 文書要約, 知識管理 . 情報処理学会会員 .

語処理, 情報学, 知識管理. A C L , 情報処理学会, 各会員.

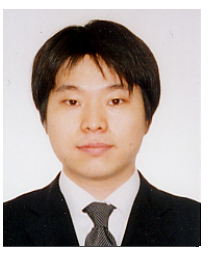

\section{森井 洋}

1975 年生. 1999 年東京大学工学部機械情 報工学科卒業. 2001 年同大学大学院工学系 研究科産業機械工学専攻修士課程修了. 同 年同専攻博士課程進学, 現在に至る.

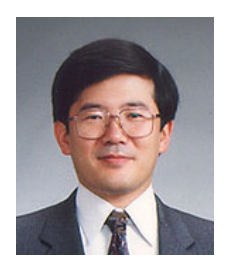

\section{中尾 政之}

東京大学工学部総合試験所教授 . 現在はナ ノ・マイクロ加工, 加工の知能化, 科学器 械の微細化などの研究に従事 . 著書「実際 の情報機器技術」(日刊工業新聞社 ,1998)， 「設計のナレッジマネジメント」（日刊工 業新聞社，1999)。

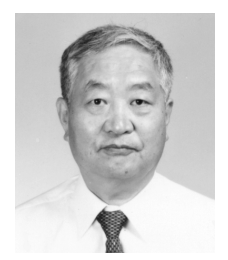

\section{畑村 洋太郎}

工学院大学国際基礎工学科教授 .ナノ・マ イクロ加工, カセンサ, 加工の知能化, 医 学支援工学，技術の伝承と教育の方法論を 研究し, 実際の設計研究会を主宰し創造設 計原理の研究を行っている. 主な編・著・ 訳書「続々・実際の設計-失敗に学ぶ・」，「実際の情報 機器技術」(以上，日刊工業新聞社），「設計の原理」 (岩波書店)，「失敗学のすすめ」（講談社）。 